\title{
Study on stripping phase conditions on the levulinic acid extraction using supported liquid membrane
}

\author{
V. Rajendaren ${ }^{1}$, S. M. Saufi ${ }^{1, *}$, M. A. K. Zahari ${ }^{1}$, A. W. Mohammad ${ }^{2}$ \\ ${ }^{1}$ Faculty of Chemical and Natural Resources Engineering, Universiti Malaysia Pahang, \\ Lebuhraya Tun Razak, 26300 Gambang, Pahang Darul Makmur, Malaysia \\ *Email: smsaufi@ump.edu.my \\ Phone: +6095492823; Fax: +6095492889 \\ ${ }^{2}$ Department of Chemical and Process Engineering, Faculty of Engineering and Built \\ Environment, Universiti Kebangsaan Malaysia, 43600 Bangi, Selangor Darul Ehsan, \\ Malaysia
}

\begin{abstract}
Levulinic acid (LA) is one of the top-twelve platform chemicals that can be produced from the biomass resources. LA production from the biomass is an environment friendly and sustainable compare to the petroleum based process. However, the separation and recovery of the LA from the biomass products is the main challenging process for reducing the overall LA production cost. Supported liquid membrane (SLM) is the most effective technique to extract and recover the desired product from the biomass products in a single step. Hence, it had a potential to be used for LA extraction. The study of the operation parameters in SLM system is very important to improve the yield of extraction and recovery of the product. In this study, different types of stripping agents such as sodium hydroxide $(\mathrm{NaOH})$, sodium carbonate, hydrochloric acid, trimethylamine, and water were tested in the SLM system to extract levulinic acid (LA). By using 0.3 M trioctylamine in 2-ethyl-1-hexanol as liquid membrane phase, it was found that $\mathrm{NaOH}$ was the best stripping agent to extract LA. The concentration of the $\mathrm{NaOH}$ stripping agent was varied from $0.25 \mathrm{M}$ to $1 \mathrm{M}$. The best stripping agent concentration was $0.5 \mathrm{M}$, which gave an LA extraction of $86 \%$ from a $10 \mathrm{~g} / \mathrm{L} \mathrm{LA}$ aqueous solution. The flow rate of the feed and stripping phase was investigated from 25 $\mathrm{mL} / \mathrm{min}$ to $125 \mathrm{~mL} / \mathrm{min}$. SLM operated at $75 \mathrm{~L} / \mathrm{min}$ was found to be adequate in reducing the boundary layer thickness at both sides of the SLM phases without any leakage of the liquid membrane and breakage of the matrix support. At the best stripping condition, $89 \%$ of the LA was extracted using $0.5 \mathrm{M} \mathrm{NaOH}$ that operated at flow rate of $75 \mathrm{~mL} / \mathrm{min}$.
\end{abstract}

Keywords: Supported liquid membrane; liquid extraction; stripping phase; levulinic acid.

\section{INTRODUCTION}

Levulinic acid (LA) is listed as one of the twelve top value added chemicals derived from biomass from over 300 biomass products [1]. The separation or recovery of organic acids like LA from other biomass byproducts is the most challenging and costly part in biorefinery [2-6]. Recently, supported liquid membrane (SLM) has gained significant attention in 
downstream process due to its high degree of selectivity and capacity during separating or recovering the desired component from the mixture [7-9]. Moreover, optimization study on the operation parameters of the SLM system can further improve the efficiency of the process.

Stripping is an important parameter in the SLM system. During this step, the extracted component via carrier in the organic liquid membrane phase will be released to the stripping phase by the stripping agent. The carrier is regenerated and restarts the extraction cycle [8,9]. This process occurs simultaneously in the SLM and prevents the accumulation of extracted components in the liquid membrane phase, hence, improving the permeation and flux [10]. The stripping agents for back extraction should have a high degree of stripping and not affect the extraction efficiency of the carrier after stripping [11]. The concentration of the stripping agents is also an important parameter that should be considered in the SLM operation. If the concentration is too high, it has a high possibility for the stripping agent to move into the feed phase through the membrane's pores [12].

An aqueous solution of an electrolyte such as acid and base is a type of stripping agent that is commonly used for the recovery of organic acids in the SLM. Sodium hydroxide $(\mathrm{NaOH})$, sodium carbonate $\left(\mathrm{Na}_{2} \mathrm{CO}_{3}\right)$ and volatile ammonia $\left(\mathrm{NH}_{3}\right)$ are examples of base stripping agents that can strip the acid and form sodium salt or ammonium salt at the stripping phase [7,11-13]. Furthermore, trimethylamine (TMA) is a water-soluble and volatile base used in the stripping phase for extracting the acid without the formation of a salt byproduct [14-16]. However, TMA is a toxic material that can affect the bioactivity of the enzyme [17]. Back extraction using acid such as hydrochloric acid $(\mathrm{HCl})$ can also be used to produce undissociated acid, but later, it would have to undergo the distillation process to regenerate the $\mathrm{HCl}$.

It was reported that the succinic acid extraction yield had increased when the striping agent concentration increased from $0.01 \mathrm{M}$ to $0.5 \mathrm{M}$ due to the delayed accumulation of acid complex in the membrane layer and $0.5 \mathrm{M}$ of $\mathrm{Na}_{2} \mathrm{CO}_{3}$ was recorded as the best stripping agent concentration for the process [18]. The results also indicated that $\mathrm{Na}_{2} \mathrm{CO}_{3}$ was performed better and resulted high succinic acid extraction yield compared to $\mathrm{NaOH}[18,19]$. However, some studies reported that $\mathrm{NaOH}$ performs better than $\mathrm{Na}_{2} \mathrm{CO}_{3}$ because of its larger reaction capacity with acid, which keeps higher hydrogen ion gradient between the feed and the stripping phases [20]. $\mathrm{NaOH}$ also showed a better recovery of lactic acid than $\mathrm{HCl}$ [11]. Keshav and Wasewar [15] has tested various concentrations of $\mathrm{NaOH}(0.02-1.0 \mathrm{M})$ and TMA $(0.05-0.31 \mathrm{M})$ as the stripping phase for the recovery of propionic acid from loaded organic phase. Based on the results, $100 \%$ of acid in the organic phase was extracted when the molar ratio of $\mathrm{NaOH}$ or TMA is slightly higher than the molar ratio of the acid in the organic phase.

Apart from that, the flow rate of the feed and strip phases are important operation parameters in the SLM system [21]. The stirring or pumping of the flow streams affects the existing pressures in the organic LM phase. Normally, the flow rate for both feed and stripping sides are set at the same value. Using different values can cause different pressures existing in the LM, thus, leading to the leakage of LM from the matrix support [22]. The effect of different flow rates as $1.35,2.07$ and $2.79 \mathrm{~L} / \mathrm{h}$ at both feed and stripping streams in the SLM for glucose extraction were investigated by [23]. Based on the study, increasing the flow rate of both streams and reducing the boundary layer thickness between the phases and membrane lead to a high degree of glucose extraction and recovery. Harruddin et al. (2017) 
[24] studied the effect of different feed flow rates and it was found that $75 \mathrm{~mL} / \mathrm{min}$ is the optimum flow rate for the acetic acid removal by their SLM system.

Hence, a study on the best operating condition of the SLM process is important to enhance the LA extraction. In the current study, a custom-made hybrid graphenepolyethersulfone membrane was fabricated and used as the membrane support in the SLM system. The effect of stripping operation parameters such as types of stripping agents and concentrations, and SLM flowrates were investigated.

\section{METHODS AND MATERIALS}

\section{Materials}

Polyethersulfone (Radel® A, Solvay, USA) was used as the base polymer for membrane fabrication. Dimethylacetamide (DMac) and polyethylene glycol (PEG 200) were purchased from Sigma Aldrich and used as a solvent and an additive, respectively. Distilled water was used as a coagulation medium. The graphene nanopowder was used as an inorganic compound, in which it was supplied by Low Dimensional Materials Research Centre, University of Malaya, Malaysia. For organic LM phase preparation, trioctylamine (TOA) was supplied by Sigma Aldrich and used as carriers, whereas the 2-ethyl-1-hexanol from Merck was used as diluents. $\mathrm{NaOH}$ (Merck), $\mathrm{Na}_{2} \mathrm{CO}_{3}$ (Merck), $\mathrm{HCl}$ (Fisher Scientific), TMA (Nacalai Tesque), and deionized water $\left(\mathrm{H}_{2} \mathrm{O}\right)$ were used as stripping agents. The LA was bought from Sigma Aldrich and used as the feed.

\section{Membrane Fabrication}

Vapor inducing phase separation (VIPS) technique was used to fabricate a microporous PES/graphene mixed matrix membrane. The casting solution was prepared from $15 \mathrm{wt} \%$ PES, 42.5 wt \% polyethyleneglycol (PEG 200) and 42.5 wt \% dimethylacetamide (DMac). The graphene nanopowder with an amount of $0.1 \mathrm{wt} \%$ relative to the total amount of PES in the casting solution was added to increase the hydrophobicity of the membrane support. The graphene nanopowder was premixed with DMac solvent $(50 \%$ based on the total wt \% of DMac solution) and ultrasonic for a day. Later, the $42.5 \mathrm{wt} \%$ of PEG 200, 15 wt $\%$ of PES and the balanced wt $\%$ of the DMac were added together with the premixed solution and continuously stirred for up to two days at room temperature until a homogeneous dope solution was formed. The prepared solution was degassed at room temperature for a day. The polymer solution was casted onto a glass plate at a thickness of $400 \mu \mathrm{m}$ by using a semiautomatic casting machine. The cast film was immediately exposed to 86-89\% of humidified

environment for 30 seconds. Later, it was immersed into a water coagulation bath at 40 for 30 minutes. Then, the solidified film was immersed into another new water coagulation bath at room temperature for a day and was dried at room temperature for two days. The prepared membrane support was cut into $11 \mathrm{~cm} \times 5 \mathrm{~cm}$ size [25].

\section{Field Emission Scanning Electron Microscope}

The membrane was fractured via freeze fracture technique by using liquid nitrogen. The membrane was then coated with platinum and its morphology was observed using Field Emission Scanning Electron Microscopy (FESEM) model JEOL JSM-5410LV, Japan. 


\section{SLM System}

A LM was prepared from $0.3 \mathrm{M}$ TOA and 2-ethyl-1-hexanol. The membrane support was immersed into the LM for a day and the excess LM on the surface of SLM was removed using filter paper. The SLM was fixed into the cell membrane, as shown in Figure 1. $10 \mathrm{~g} / \mathrm{L}$ LA solution was used in the feed phase. The effect of $0.5 \mathrm{M}$ of each stripping agent $(\mathrm{NaOH}$, $\mathrm{Na}_{2} \mathrm{CO}_{3}, \mathrm{HCl}$, TMA, and $\mathrm{H}_{2} \mathrm{O}$ ) at the stripping phase on the LA extraction yield was evaluated. The concentration of the best stripping agent that ranged from $0.25 \mathrm{M}, 0.5 \mathrm{M}, 0.75$ $\mathrm{M}$, and $1 \mathrm{M}$ was also evaluated. Two-channel peristaltic pump was used to pump the solutions into the membrane cell in counter-current flow, as shown in Figure 1. The effect of flow rate of the feed and stripping phases that ranged from $25 \mathrm{~mL} / \mathrm{min}, 50 \mathrm{~mL} / \mathrm{min}, 75 \mathrm{~mL} / \mathrm{min}, 100$ $\mathrm{mL} / \mathrm{min}$, and $125 \mathrm{~mL} / \mathrm{min}$ on the extraction yield of LA was investigated. The samples were taken from the feed phase every two hours for the period of eight hours [25].

\section{LA Extraction Percentage}

The samples were analyzed by using the Synergy Hydro C18 high performance liquid chromatography (HPLC) column (Phenomenex, $250 \mathrm{~mm} \times 4.6 \mathrm{~mm}, 4 \mu \mathrm{m}$ particle size) that is connected to the Agilent HPLC 1200 system. The $0.02 \mathrm{M}$ potassium dihydrogen phosphate was adjusted to a $\mathrm{pH}$ value of 2.9 and used as a mobile phase. The LA was detected through an ultraviolet (UV) detector at $221 \mathrm{~nm}$ wavelength. The column was operated for 22 minutes at $30^{\circ} \mathrm{C}$ with a flow rate of $8 \mathrm{~mL} / \mathrm{min}$. Equation (1) was used to calculate the percentage of LA extraction during the SLM process [25].

$$
\text { Extraction }(\%)=\frac{[L A]_{f i}-[L A]_{f o}}{[L A]_{f i}} \times 100 \%
$$

where, $[\mathrm{LA}]_{\mathrm{fi}}$ is the initial concentration of LA in the feed phase, and $[\mathrm{LA}]_{\mathrm{fo}}$ is the final concentration of LA in the feed phase.

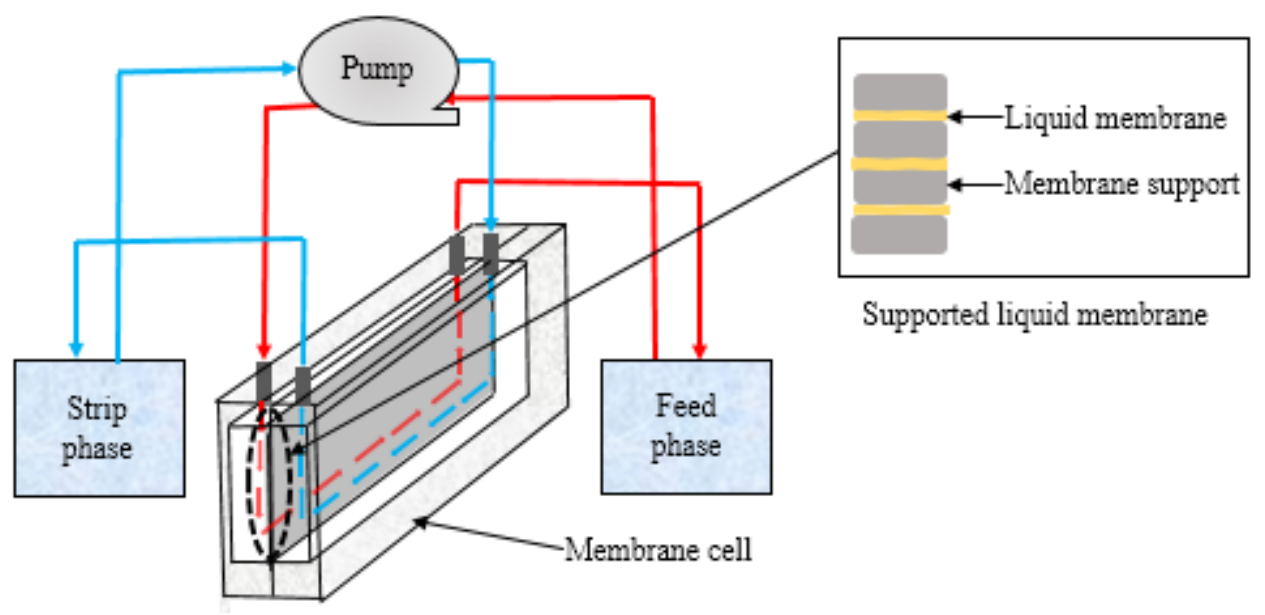

Figure 1. SLM system 


\section{RESULTS AND DISCUSSION}

\section{Membrane Morphology}

The cross sectional structure of the hybrid PES/graphene membrane support was showed in Figure 2. It shows a long cylindrical microvoid structure that connected from the top to the bottom surface of the membrane. This same type of the membrane was successfully used for extraction of acetic acid using SLM process previously [9].

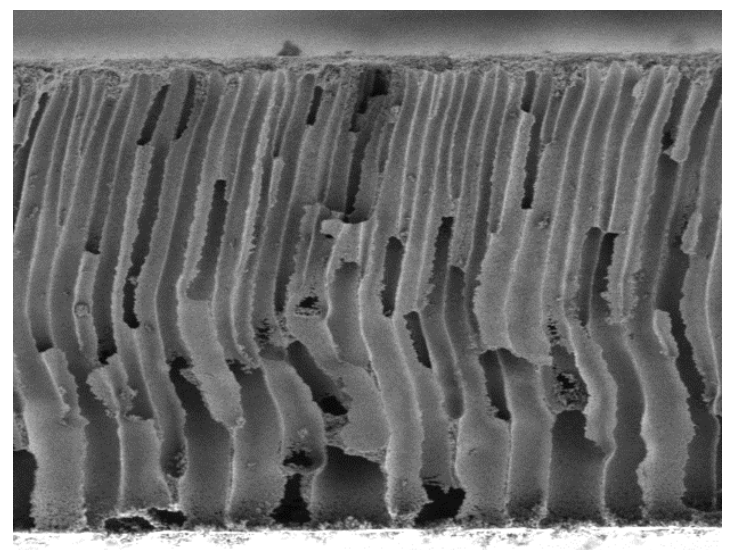

Figure 2. Cross section of PES/graphene hybrid membrane.

\section{Effect of Types of Stripping Agents}

In the SLM system, the $\mathrm{pH}$ difference between the feed and stripping phases plays a vital role in LA extraction [18]. Therefore, two types of alkaline striping phase were tested, which were $\mathrm{NaOH}$ and $\mathrm{Na}_{2} \mathrm{CO}_{3}$. The extraction yield of LA using various types of stripping agents at $0.5 \mathrm{M}$ concentration was showed in Figure 3. The extraction yield of LA stripped using $\mathrm{NaOH}$ is higher, with $86 \%$ compared to $\mathrm{Na}_{2} \mathrm{CO}_{3}$, of only $59 \%$. The initial $\mathrm{pH}$ values of aqueous $\mathrm{Na}_{2} \mathrm{CO}_{3}$ and $\mathrm{NaOH}$ were recorded as 9.83 and 13.54 , respectively. Hence, $\mathrm{NaOH}$ is a strong base and it dissociates completely in water to form one mole of $\mathrm{Na}^{+}$and $\mathrm{OH}^{-}$. Meanwhile, $\mathrm{Na}_{2} \mathrm{CO}_{3}$ is a weak base that dissociates in water to form two moles of $\mathrm{Na}^{+}$and one mole of $\mathrm{CO}_{3}{ }^{2-}$. The total molar concentration of sodium ions $\left(\mathrm{Na}^{+}\right)$in $\mathrm{Na}_{2} \mathrm{CO}_{3}$ and $\mathrm{NaOH}$ are $1 \mathrm{~mol} / \mathrm{L}$ and $0.5 \mathrm{~mol} / \mathrm{L}$, respectively. It has been stated that the stripping phase with higher concentration of sodium ion can extract more acid $[18,19]$. However, the $\mathrm{OH}^{-}$group possesses high base strength than the $\mathrm{CO}_{3}{ }^{2-}$ does. Therefore, the $\mathrm{NaOH}$ easily undergoes base ionization in water and efficiently reacts and extracts the acid from the loaded carrier compared to the $\mathrm{Na}_{2} \mathrm{CO}_{3}$.

The LA extraction yield for acid-based stripping solution of $\mathrm{HCl}$ showed the least, with only $14 \%$. The $\mathrm{HCl}$ and LA are classified as acid and both can be extracted by TOA. However, the $\mathrm{HCl}$ is a strong acid and a good proton donor, which easily dissociates into a proton, $\mathrm{H}^{+}$and effectively reacts with the lone pair in amine (TOA) compared to the LA. Moreover, it has been stated that $\mathrm{HCl}$ can easily displace the organic acid from the loaded carrier $[11,26,27]$. In this case, the $\mathrm{HCl}$ at the stripping phase was extracted via the carrier and the $\mathrm{HCl}$ had also displaced the LA from the loaded carrier in the LM. Therefore, $\mathrm{HCl}$ resulted in the least LA extraction yield. Hence, $\mathrm{HCl}$ is not recommended for acid-back extraction in this SLM system. 


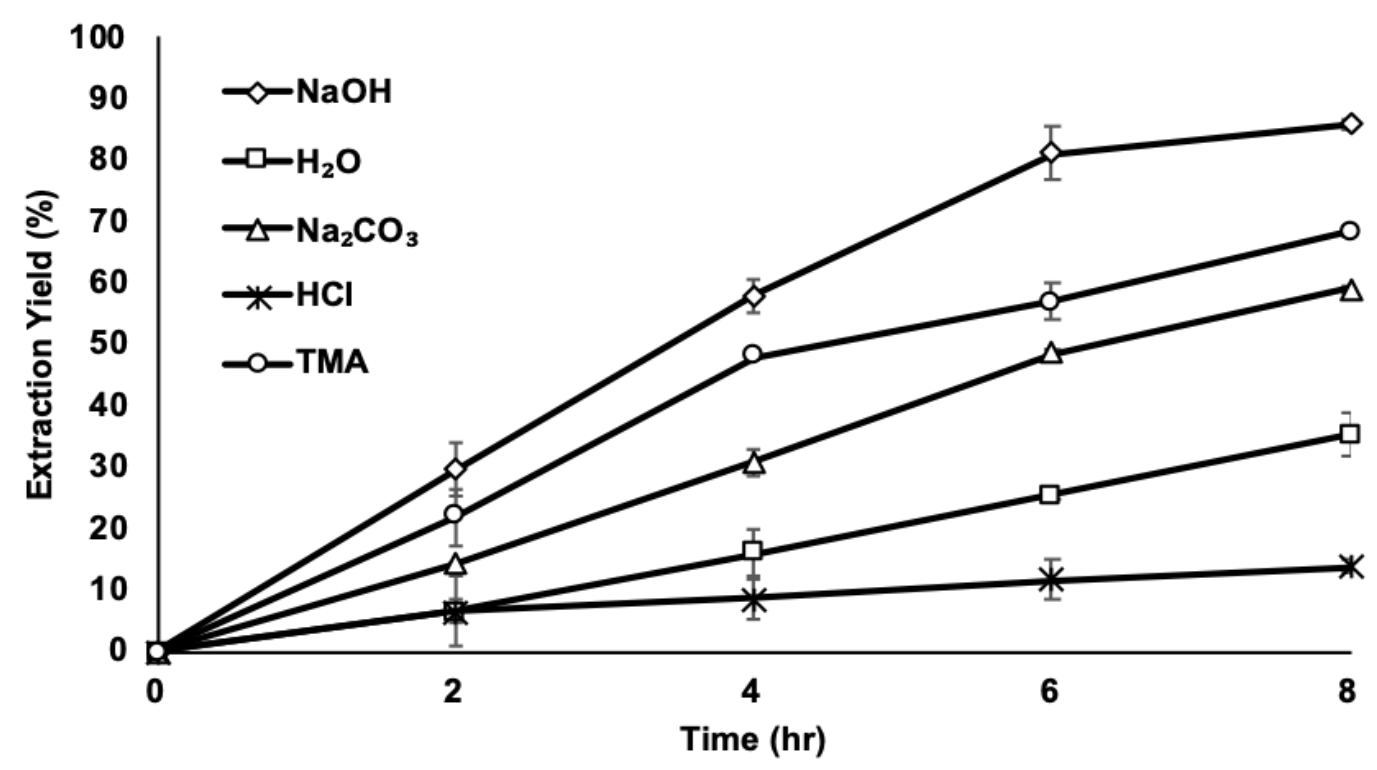

Figure 3. Extraction yield of LA using 0.5 M of various types of stripping agents. (Experimental condition: feed phase - $10 \mathrm{~g} / \mathrm{L} \mathrm{LA}$; LM phase - $0.3 \mathrm{M}$ TOA in 2-ethyl-1hexanol; flow rate $-50 \mathrm{~mL} / \mathrm{min}$ )

In eight hours, $35 \%$ of LA was extracted using the $\mathrm{H}_{2} \mathrm{O}$ stripping phase. Water is a neutral compound with $\mathrm{pH} 7$, resulting in a low $\mathrm{pH}$ difference between the feed and stripping phases compared to other striping agents. The extraction yield using $\mathrm{H}_{2} \mathrm{O}$ is low compared to the $\mathrm{NaOH}, \mathrm{Na}_{2} \mathrm{CO}_{3}$ and TMA, which possessed high $\mathrm{pH}$ values of 13.54, 9.83 and 11.50, respectively. Theoretically, high $\mathrm{pH}$ difference between the feed and stripping phases provide a better stripping efficiency [11].

Stripping using TMA showed an LA extraction yield of 68\%. TMA can dissolve in water and has a high capability of re-extracting the organic acid from the loaded carrier [11]. Hence, it is suitable to be used as a stripping agent at the stripping phase of SLM. By using TMA as the stripping phase, the formation of salt byproduct can be prevented [28]. Furthermore, it is a high volatile base that can be easily separated from the extracted LA by distillation process at low temperature [11]. However, the extraction yield using TMA is still low compared to the $\mathrm{NaOH}$ stripping agent. Therefore, $\mathrm{NaOH}$ was selected for further study to investigate the effect of the stripping agent concentration on the LA extraction yield.

\section{Effect of Stripping Agent Concentration}

Based on Figure 4, the LA extraction was increased when the $\mathrm{NaOH}$ concentrations were increased from $0.25 \mathrm{M}$ to $0.5 \mathrm{M}$. Further increment on the $\mathrm{NaOH}$ concentration to $0.75 \mathrm{M}$ and $1 \mathrm{M}$ had reduced the LA extraction yield. $0.5 \mathrm{M}$ of $\mathrm{NaOH}$ was recorded as the best concentration for stripping with the extraction yield of $86 \% .0 .25 \mathrm{M}$ of $\mathrm{NaOH}$ resulted in the very least extraction yield of $75 \%$ because it only possessed a small amount of $\mathrm{Na}^{+}$to extract the acid. It consisted of more $\mathrm{H}_{2} \mathrm{O}$ molecules, which acts as a barrier for the $\mathrm{Na}^{+}$to interact 
with the acid-amine complex in the LM. The increase in $\mathrm{NaOH}$ concentration can cause an increase in the space availability for $\mathrm{Na}^{+}$at the stripping phase. Therefore, it rapidly interacted with the acid-amine complex and easily extracted the LA. This prevented the accumulation of acid complex in the LM, thus improving the efficiency of stripping. However, further increase in the $\mathrm{NaOH}$ concentrations to $0.75 \mathrm{M}$ and $1 \mathrm{M}$ had decreased the extraction yield to $79 \%$ and $77 \%$, respectively. This is because a further increase in the stripping concentration had caused an increase in the viscosity of the $\mathrm{NaOH}$ solution. According to the Poiseuille's Law, the flow rate is inversely proportional to the viscosity of a solution. Hence, the additional $\mathrm{NaOH}$ had increased the viscosity and reduced the flow rate at the stripping phase. The low flow rate level is insufficient to prevent and reduce the boundary layer formation on the surface of SLM at the stripping phase, as shown in Figure 5.

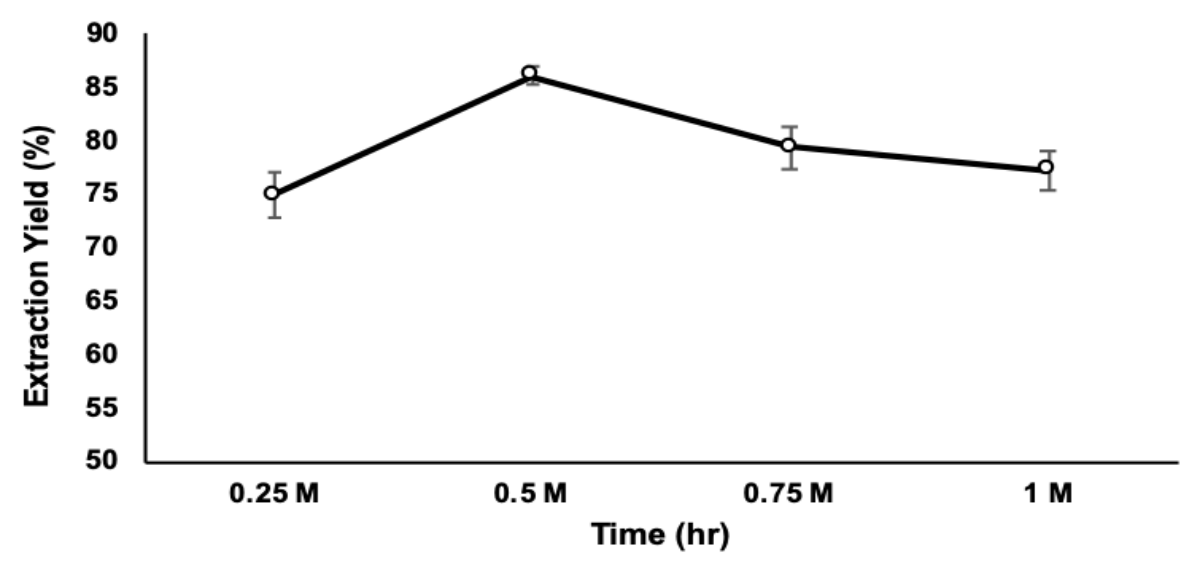

Figure 4. Extraction yield of LA using different concentrations of $\mathrm{NaOH}$ stripping agents. (Experimental condition: feed phase - $10 \mathrm{~g} / \mathrm{L}$ LA; LM phase - $0.3 \mathrm{M}$ TOA in 2-ethyl-1hexanol; flow rate $-50 \mathrm{~mL} / \mathrm{min}$ )

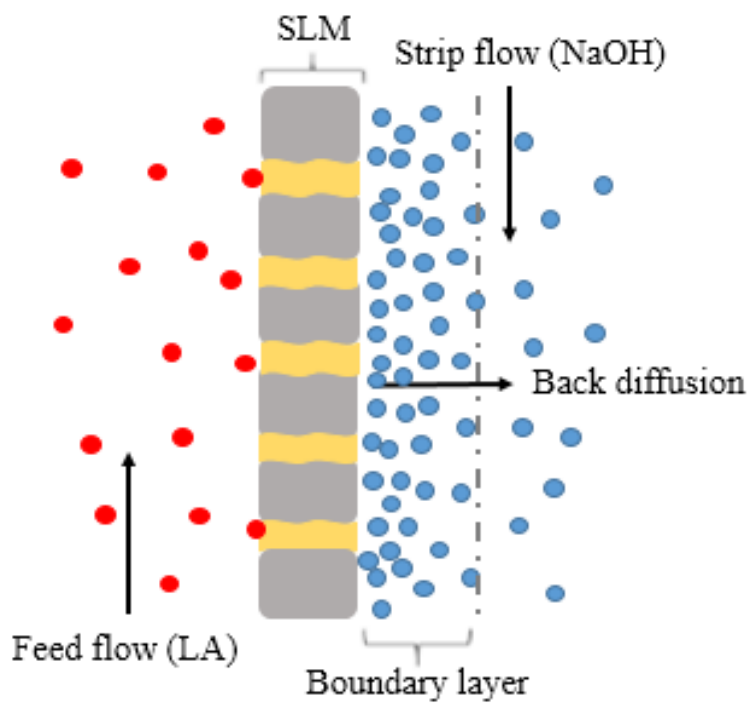

Figure 5. Formation of boundary layer on the surface of membrane support in SLM process 
Thicker boundary layer can increase the osmotic pressure close to the membrane surface, in which it can diffuse the $\mathrm{Na}^{+}$back from the membrane support to the bulk solution. Thus, it will reduce the LA extraction yield. Furthermore, the pressure that exists at the stripping phase increases when high concentration of stripping agent was used. This will induce an imbalance pressure between the feed and stripping phases, causing the leakage of LM from the membrane support [22]. Hence, $0.5 \mathrm{M}$ of $\mathrm{NaOH}$ was chosen as the best stripping agent concentration for LA extraction in this study.

\section{Effect of SLM Flow Rate}

In this study, the flow rates of the feed and stripping phases were kept at the same value to avoid the leakage of LM from the membrane support and breakage of the membrane support. Different flow rates at the feed and stripping phase can lead to different pressures existing in the SLM [22]. The effect of the SLM flow rate from $25 \mathrm{~mL} / \mathrm{min}$ to $125 \mathrm{~mL} / \mathrm{min}$ on the LA extraction yield is showed in Figure 6. The LA extraction yield increased, as the flow rate increased from $25 \mathrm{~mL} / \mathrm{min}$ to $75 \mathrm{~mL} / \mathrm{min}$, reaching a maximum extraction at $75 \mathrm{~mL} / \mathrm{min}$ and then decreased as the flow rate increased from $75 \mathrm{~mL} / \mathrm{min}$ to $125 \mathrm{~mL} / \mathrm{min}$. The lowest LA extraction yield (74\%) was obtained at $25 \mathrm{~mL} / \mathrm{min}$ because it was insufficient to reduce the boundary layer formation near the membrane surface in both the feed and stripping phases. $75 \mathrm{~mL} / \mathrm{min}$ is the best flow rate that resulted in the highest extraction yield of $89 \%$. It had successfully reduced the boundary thickness at both sides of the SLM without any leakage of the LM and breakage of the matrix support. Further increase in flow rate to $100 \mathrm{~mL} / \mathrm{min}$ and $125 \mathrm{~mL} / \mathrm{min}$ did not improve the extraction efficiency, but had reduced the LA extraction yield to $82 \%$ and $79 \%$, respectively. This is because too high flow rate can cause high pressure in the SLM due to the formation of turbulence flow at both the feed and stripping phases. This phenomenon can cause high possibility for LM leakage and matrix support breakage [22].

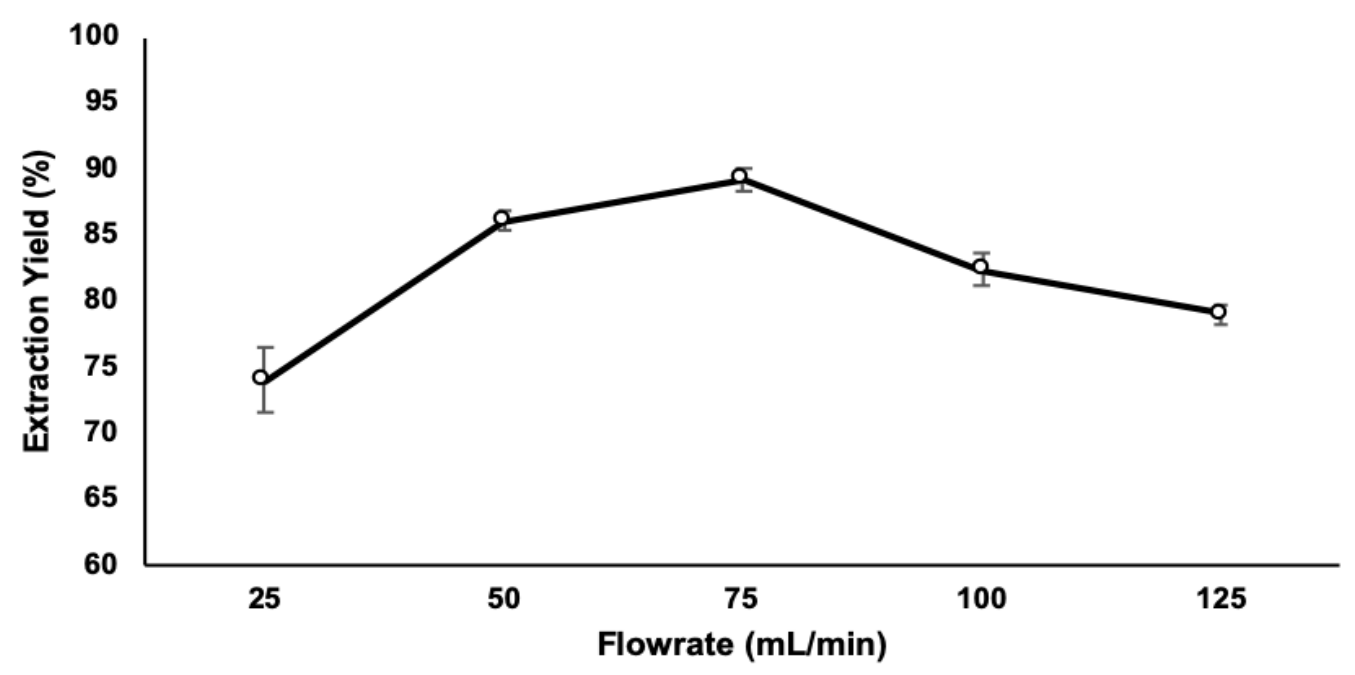

Figure 6. Extraction yield of LA after eight hour using different SLM flow rate. (Experimental condition: feed phase - 10 g/L LA; LM phase - 0.3 M TOA in 2-ethyl-1hexanol; stripping phase - $0.5 \mathrm{M} \mathrm{NaOH}$ ) 
Table 1 showed the LA extraction yield using various methods. The lowest LA extraction yield obtained from this study is $13.8 \%$ when $\mathrm{HCl}$ was used as the stripping agent. Thereafter, $\mathrm{NaOH}$ was selected as the best stripping agent. By adjusting the stripping operation parameters, the LA extraction yield increased to the highest value of $89 \%$. This value is higher than the conventional liquid-liquid extraction process that using methyl-isobutyl ketone (MIBK) [29] and dichloromethane [30] extractant. Although, the extraction yield using SLM process is lower compare to the reactive liquid extraction process [30], SLM process had advantage in term of single operation step compare to reactive liquid extraction method. Another variation of liquid membrane, which is bulk liquid membrane (BLM) showed higher LA extraction yield than the SLM process using in this study [31]. However, BLM requires a large amount of organic liquid membrane compared to SLM and will increase the overall separation cost [32]. Thus, SLM is a more preferable technique than BLM.

Table 1 Different types of extraction methods for LA separation

\begin{tabular}{|c|c|c|c|}
\hline Methods & Description & $\begin{array}{c}\text { Yield } \\
(\%)\end{array}$ & Reference \\
\hline $\begin{array}{l}\text { Supported } \\
\text { Liquid } \\
\text { Membrane } \\
\text { (SLM) }\end{array}$ & $\begin{array}{l}\text { Extraction of LA from } 10 \mathrm{~g} / \mathrm{L} \text { LA aqueous } \\
\text { solution using } 0.3 \mathrm{M} \text { TOA and 2-ethyl-1- } \\
\text { hexanol liquid membrane incubated in } \\
\text { hybrid PES/graphene membrane support. }\end{array}$ & 89 & This study \\
\hline \multirow[t]{2}{*}{$\begin{array}{l}\text { Physical } \\
\text { Extraction }\end{array}$} & $\begin{array}{l}\text { Extraction of LA from } 0.1099 \mathrm{~mol} \cdot \mathrm{kg}^{-1} \mathrm{LA} \\
\text { using Methyl-iso-butyl ketone (MIBK) }\end{array}$ & 41.07 & [29] \\
\hline & $\begin{array}{l}\text { Extraction of LA from } 0.5 \mathrm{kmol} . \mathrm{m}^{-3} \text { of LA } \\
\text { solution using dichloromethane }\end{array}$ & 37.8 & {$[30]$} \\
\hline \multirow[t]{2}{*}{$\begin{array}{l}\text { Reactive } \\
\text { extraction }\end{array}$} & $\begin{array}{l}\text { Extraction of LA from } 0.2795 \mathrm{~mol} \cdot \mathrm{kg}^{-1} \mathrm{LA} \\
\text { using mixture of Aliquat } 336 \text { and } \\
\text { dichloromethane }\end{array}$ & 67.55 & [29] \\
\hline & $\begin{array}{l}\text { Extraction of LA from } 0.5 \mathrm{kmol} . \mathrm{m}^{-3} \text { of LA } \\
\text { solution using mixture of TOA in } \\
\text { dichloromethane }\end{array}$ & 98.7 & {$[30]$} \\
\hline $\begin{array}{l}\text { Bulk Liquid } \\
\text { Membrane } \\
\text { (BLM) }\end{array}$ & $\begin{array}{l}\text { Extraction of LA from } 6.015 \% \mathrm{w} / \mathrm{w} \text { of LA } \\
\text { solution using mixture of tributyl phosphate } \\
\text { in 1-butyl-3-methylimidazolium } \\
\text { bis(trifluoromethylsulfonyl)imide }\end{array}$ & 98.63 & [31] \\
\hline
\end{tabular}




\section{CONCLUSIONS}

In this study, the operation parameters in the SLM such as the types and concentrations of stripping agents and SLM flow rate were tested. These parameters have a great impact on the extraction efficiency of LA. The best stripping solution is $\mathrm{NaOH}$ solution at $0.5 \mathrm{M}$ operated using flow rate of $75 \mathrm{~mL} / \mathrm{min}$. The system was able to extracted $89 \%$ of LA from $10 \mathrm{~g} / \mathrm{L}$ aqueous LA feed solution using 0.3 M TOA in 2-ethyl-1-hexanol as the organic liquid membrane phase. In conclusion, SLM is a simple low cost process which able to promote highly selective separation with a small amount of organic liquid membrane. However, loss of liquid membrane and short life time of membrane support are the main problems in SLM that required further improvement. In order to enhance the extraction yield of the LA, optimization of the membrane support can be considered in the future studies. Less attention has been given on the development of the best membrane support in SLM process in the past studies due to the use of commercial membrane support.

\section{ACKNOWLEDGEMENTS}

This study was financially supported by the Fundamental Research Grant Scheme (RDU170117 - FRGS/1/2017/TK02/UMP/02/8) awarded by the Ministry of Education, Malaysia.

\section{REFERENCES}

[1] Aden A, Bozell J, Holladay J, White J, Manheim A. Top value added chemicals from biomass volume i: results of screening for potential candidates from sugars and synthesis gas. National Renewable Energy Lab Report. 2004.

[2] Cramer SM, Holstein MA. Downstream bioprocessing: recent advances and future promise. Current Opinion in Chemical Engineering 2011; 1(1): 27-37.

[3] Zidi C, Tayeb R, Dhahbi M. Extraction of phenol from aqueous solutions by means of supported liquid membrane ( MLS ) containing tri- $\mathrm{n}$-octyl phosphine oxide ( TOPO ). Journal of Hazardous Materials 2011; 194: 62-68.

[4] Frost M, Zydney AL. The effect of membrane properties on the separation of protein charge variants using ultrafiltration. Journal of Membrane Science 2004; 243: 379388.

[5] Brouwer T, Blahusiak M, Babic K, Schuur B. Reactive extraction and recovery of levulinic acid, formic acid and furfural from aqueous solutions containing sulphuric acid. Separation and Purification Technology 2017; 185: 186-195.

[6] Lin X, Huang Q, Qi G, Shi S, Xiong L, Huang C. Estimation of fixed-bed column parameters and mathematical modeling of breakthrough behaviors for adsorption of levulinic acid from aqueous solution using SY-01 resin. Separation and Purification Technology 2017; 174: 222-231.

[7] Yu J, Li H, Liu H. Recovery of acetic acid over water by pervaporation with a combination of hydrophobic ionic liquids. Chemical Engineering Communications 2006; 193(11): 1422-1430. 
[8] Molinari R, Argurio P. Applications of supported liquid membranes and emulsion liquid membranes. Encyclopedia of Membrane Science and Technology 2013: 1-21.

[9] Harruddin N, Saufi SM, Faizal CKM, Mohammad AW. Effect of VIPS fabrication parameters on the removal of acetic acid by supported liquid membrane using a PES - graphene membrane support. The Royal Society of Chemistry 2018; 8(45): 2539625408.

[10] Yang X, Duan H, Shi D, Yang R, Wang S, Guo H. Facilitated transport of phenol through supported liquid membrane containing bis ( 2-ethylhexyl) sulfoxide ( BESO ) as the carrier. Chemical Engineering \& Processing: Process Intensification 2015; 93: 79-86.

[11] Kyuchoukov G, Yankov D. Theoretical and experimental study of lactic acid stripping from loaded organic phase. Industrial \& Engineering Chemistry Research 2010; 49: 8238-8243.

[12] Surucu A, Eyupoglu V, Tutkun O. Selective separation of cobalt and nickel by flat sheet supported liquid membrane using Alamine 300 as carrier. Journal of Industrial and Engineering Chemistry 2012; 18(2): 629-634.

[13] Patil ND, Patwardhan AW, Patwardhan A V. Carboxylic acids separation using hollow fiber supported liquid membrane. Indian Journal of Chemical Technology 2017; 24: 20-31.

[14] Kocherginsky NM, Yang Q, Seelam L. Recent advances in supported liquid membrane technology. Separation and Purification Technology 2007; 53(2): 171177.

[15] Keshav A, Wasewar KL. Back extraction of propionic acid from loaded organic phase. Chemical Engineering Science 2010; 65: 2751-2757.

[16] Manzak A, Sonmezoglu M. Extraction of acetic acid from aqueous solutions by emulsion type liquid membranes using Alamine 300 as a carrier. Indian Journal of Chemical Technology 2010; 17: 441-445.

[17] Wasewar KL, Yawalkar AA, Moulijn JA, Pangarkar VG. Fermentation of glucose to lactic acid coupled with reactive extraction: a review. Industrial \& Engineering Chemistry Research 2004; 43: 5969-5982.

[18] Jusoh N, Othman N, Nasruddin NA. Emulsion liquid membrane in organic acid purification. Malaysian Journal of Analytical Sciences 2015; 20(2): 436-443.

[19] Lee SC. Extraction of succinic acid from simulated media by emulsion liquid membranes. Journal of Membrane Science 2011; 381: 237-243.

[20] Nasruddin NA, Othman N, Idris A, Jusoh N. Liquid membrane component selection for succinic acid extraction. Jurnal Teknologi 2014; 69(4): 73-76.

[21] Manna MS, Saha P, Ghoshal AK. Separation of medicinal catechins from tea leaves (Camellia sinensis) extract using hollow fiber supported liquid membrane ( HF-SLM ) module. Journal of Membrane Science 2014; 471: 219-226.

[22] Manna MS, Saha P, Ghoshal AK. Studies on the stability of a supported liquid membrane and its cleaning protocol. RSC Advances 2015; 5: 71999-72008.

[23] Teng SS, Harruddin N, Saufi SM. Extraction of glucose by supported liquid membrane using polyethersulfone flat sheet membrane support. Applied Membrane Science \& Technology 2017; 20(1): 1-9.

[24] Harruddin N, Saufi SM, Faizal CKM, Mohammad AW. Removal of acetic acid from aqueous solution by polyethersulfone supported liquid membrane. Chemical 
Engineering Transactions 2017; 56: 847-852.

[25] Harruddin N, Saufi SM, Faizal CKM, Mohammad AW, Ming HN. Supported liquid membrane using hybrid polyethersulfone/ graphene flat sheet membrane for acetic acid removal. Journal of Physical Science 2017; 28(Supp. 1): 111-120.

[26] Wasewar KL. Reactive Extraction: An intensifying approach for carboxylic acid separation. International Journal of Chemical Engineering and Applications 2012; 3(4): 249-255.

[27] Kumar S, Babu B V, Wasewar KL. Recovery of propionic acid using reactive extraction. Proceedings of International Symposium \& 59th Annual Session of IIChE (CHEMCON-2006), Bharuch, December 27-30., 2006.

[28] Keshav A, Chand S, Wasewar KL. Recovery of propionic acid from aqueous phase by reactive extraction using quarternary amine (Aliquat 336 ) in various diluents. Chemical Engineering Journal 2009; 152(1): 95-102.

[29] Datta D, Marti ME, Pal D, Kumar S. Equilibrium study on the extraction of levulinic acid from aqueous solution with Aliquat 336 dissolved in different diluents : solvent's polarity effect and column design. Journal of Chemical \& Engineering Data 2016; 62(1): 3-10.

[30] Kumar S, Uslu H, Datta D, Rarotra S, Rajput K. Investigation of extraction of 4-oxopentanoic acid by n,n-dioctyloctan-1-amine in six different diluents: equilibrium study. Journal of Chemical and Engineering Data 2015; 60(5): 14471453.

[31] Baylan N, Cehreli Su. Ionic liquids as bulk liquid membranes on levulinic acid removal: A design study. Journal of Molecular Liquids 2018; 266: 299-308.

[32] Teng TT, Talebi A. Green liquid membrane : development and challenges. Journal of Membrane Science \& Technology 2012; 2(3): 2-3. 